\title{
Managing Spent Nuclear Fuel At The Idaho National Laboratory
}

\section{NATO/IAEA Advanced Research Workshop}

\author{
Thomas J. Hill
}

Denzel L. Fillmore

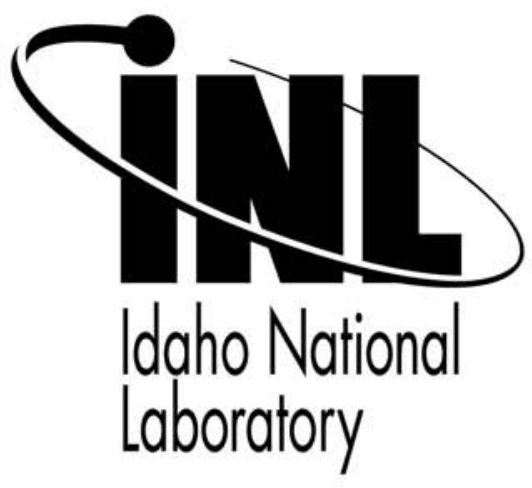

This is a preprint of a paper intended for publication in a journal or proceedings. Since changes may not be made before publication, this preprint should not be cited or reproduced without permission of the author. This document was prepared as an account of work sponsored by an agency of the United States Government. Neither the United States Government nor any agency thereof, or any of their employees, makes any warranty, expressed or implied, or assumes any legal liability or responsibility for any third party's use, or the results of such use, of any information, apparatus, product or process disclosed in this report, or represents that its use by such third party would not infringe privately owned rights. The views expressed in this paper are not necessarily those of the United States Government or the sponsoring agency. 


\title{
MANAGING SPENT NUCLEAR FUEL AT THE IDAHO NATIONAL LABORATORY
}

\author{
SHORT TITLE: MANAGING SPENT NUCLEAR FUEL AT INL \\ THOMAS J. HILL* \\ DENZEL L. FILLMORE \\ Idaho National Laboratory, Idaho Idaho Closure Project, Idaho
}

\begin{abstract}
The Idaho National Laboratory (INL) has a large inventory of diverse types of spent nuclear fuel (SNF). This legacy derives from the history of the INL as the National Reactor Testing Station, and from its mission to recover HEU from SNF and to test and examine SNF after irradiation. The INL also has a large diversity of SNF storage facilities, some 50 years old.

SNF at INL has many forms - from intact assemblies down to metallurgical mounts, and some fuel has been wet stored for over 40 years. SNF is stored bare or in metal cans under water, or dry in vaults, caissons or casks. Inspection shows varying corrosion and degradation of the SNF and its storage cans.

SNF has been stored in 10 different facilities: 5 pools, one cask storage pad, one vault, two generations of caisson facilities, and one modular Independent Spent Fuel Storage Installation (ISFSI). The pools range in age from 40 years old to the most modern in the US Department of Energy (DOE) complex. The near-term objective is to move SNF from older pools to interim dry storage, allowing shutdown and decommissioning of the older facilities. This move involves drying methods that are dependent on fuel type.

The long-term objective is to have INL SNF in safe dry storage and ready to be shipped to the National Repository. The unique features of the INL SNF requires special treatments and packaging to meet the proposed repository acceptance criteria and SNF will be repackaged in standardized canisters for shipment and disposal in the National Repository. Disposal will use the standardized canisters that can be co-disposed with High Level Waste glass logs to limit the total fissile material in a repository waste package. The DOE standardized canister also simplifies the repository handling of the multitude of DOE SNF sizes and shapes.
\end{abstract}

Keywords: Spent Nuclear Fuel, Dry Storage, Wet Storage, Drying Spent Nuclear Fuel

\footnotetext{
*To whom correspondence should be addressed: Thomas J. Hill, Space Nuclear Systems \& Technology, Idaho National Laboratory, PO Box 1625, Idaho Falls, Idaho 83415, USA; e-mail: Thomas.hill@inl.gov
} 


\section{Introduction}

The Idaho National Laboratory (INL) was established in 1949 as the National Reactor Testing Station. As the name implies, the mission was reactor testing. Over the years, 52 reactors were constructed and operated by a variety of organizations for a variety of programs. Portions of the site operated under different Federal Agencies and field offices of the Atomic Energy Commission /Department of Energy (DOE). Most of the spent nuclear fuel (SNF) generated by these reactors has remained on site. A chemical reprocessing facility was constructed in 1950 for the recovery of fissile materials from SNF. SNF was also sent to the INL from many other locations for testing, examination, and reprocessing. Sources of this SNF included naval reactors, DOE and university test reactors, and even some commercial reactors.

SNF was stored in a number of facilities at several different locations, including: Test Area North (TAN), Materials and Fuel Complex (MFC) [formerly Argonne National Laboratory-West], Idaho Nuclear Technology and Engineering Center (INTEC), Reactor Technology Complex (RTC), and Power Burst Facility (PBF). Much of the fuel was reprocessed for the recovery of enriched uranium. At present, 257 Metric Tones of Heavy Metal (MTHM) with over 250 different types of SNF is being managed at four facilities at the INL. This paper addresses management of all SNF at the INL, except for naval fuel.

\section{INL Current Status}

\subsection{SPENT NUCLEAR FUEL DESCRIPTION}

There are many characteristics of SNF important to its management. Chemical characteristics of its fabrication materials, such as the fuel meat and cladding, and other constituents, determine how it can be stored and what treatment may be required for it to meet geologic repository acceptance criteria. Physical characteristics such as length, weight, heat generation rate, radiation levels, fissile content and enrichment, and its physical condition, dictate storage and handling requirements.

The INL has a large inventory of diverse types of SNF, possibly the most diverse and varied inventory in the world. To illustrate the point, Table 1 gives some of the materials of fabrication and Table 2 describes the variety in physical characteristics of the fuel. The fuel also consists of several different fissile materials of varying enrichments. Much of the SNF is highly enriched in ${ }^{235} \mathrm{U}(>60 \%)$ and was sent to the INL for ${ }^{235} \mathrm{U}$ recovery. There is also a significant quantity of typical commercial light water reactor fuel that was brought to the INL for examination and testing. The INL also stores fuel that contains ${ }^{233} \mathrm{U}$ and thorium. Specialized test reactor fuel such as the sodium- 
bonded metal fuel used in the Experimental Breeder Reactor-II is also stored on-site.

In order to understand the inventory and quantity of the SNF, the projected 2035 inventory was placed into groups based on fabrication materials. Table 3 describes the 16 groups.

TABLE 1. Typical INL SNF Fabrication Materials

\begin{tabular}{|c|c|c|}
\hline Cladding material & $\begin{array}{c}\text { Fuel Meat } \\
\text { Composition }\end{array}$ & Other Materials \\
\hline $\begin{array}{c}\text { Aluminum } \\
\text { Stainless Steel } \\
\text { Zirconium }\end{array}$ & $\begin{array}{c}\text { Uranium Metal } \\
\text { Uranium Oxide } \\
\text { Uranium Alloy } \\
\text { Uranium Carbide }\end{array}$ & $\begin{array}{c}\text { Stainless Steels } \\
\text { Thorium Carbide } \\
\text { Beryllium Oxide } \\
\text { Metallic Sodium } \\
\text { Thorium Oxide }\end{array}$ \\
\hline
\end{tabular}

TABLE 2. INL SNF Physical Characteristics

\begin{tabular}{|l|l|}
\hline Characteristic & Range \\
\hline Weight & 0.01 to $1600 \mathrm{~kg}$ \\
\hline Length & 10 to $410 \mathrm{~cm}$ \\
\hline Heat generation rate & 0 to $600 \mathrm{w}$ \\
\hline Radiation field & 0 to $10,000 \mathrm{R} / \mathrm{hr}$ \\
\hline Weight & Scrap to excellent \\
\hline
\end{tabular}

The SNF is stored in a variety of configurations. Some is stored dry in casks, caissons, underground silos, or vaults, and much is stored underwater in spent fuel pools. Some fuel is stored unencapsulated as bare units, either intact or having had structural material removed. Some fuel is stored in containers, sometimes referred to as cans, having been previously disassembled for destructive examination or security purposes. At one time the cans were dry on the inside; however, a number are now known to have leaked. Some cans have been replaced underwater to retain the fuel handling capability. Some fuel has been in storage for $>40$ years and physical degradation has occurred.

\subsection{STORAGE FACILITY DESCRIPTION}

\subsubsection{Wet Storage Facilities}

Both wet and dry storage are used at the INL. The fuel stored wet is in concrete pools, some lined with stainless steel, either at the INL reactor site or at INTEC, the non-reactor facility formerly the Idaho Chemical Processing Plant (ICPP). 
TABLE 3. SNF Inventory Groups at INL

\begin{tabular}{|c|c|c|c|}
\hline Group & Group Description & Quantity & Fuel Example \\
\hline 1 & $\begin{array}{l}\text { Intact, low enriched }(<5 \%), \mathrm{UO}_{2} \\
\text { clad with } \mathrm{Zr} \text { or stainless steel }\end{array}$ & $\begin{array}{l}31 \text { types; } 30 \mathrm{~m}^{3} \\
76.8 \mathrm{MTHM}\end{array}$ & $\begin{array}{c}\text { Typical } \\
\text { commercial }\end{array}$ \\
\hline 2 & $\begin{array}{l}\text { Intact, medium enriched (5-20\%), } \\
\mathrm{UO}_{2} \text { clad with } \mathrm{Zr} \text { or stainless steel }\end{array}$ & $\begin{array}{l}8 \text { types; } 1.4 \mathrm{~m}^{3} \\
4 \text { MTHM }\end{array}$ & PBF \\
\hline 3 & $\begin{array}{l}\text { Intact, highly enriched }(>20 \%) \mathrm{UO}_{2} \\
\text { clad with } \mathrm{Zr} \text { or stainless steel }\end{array}$ & $\begin{array}{l}21 \text { types; } 9.3 \mathrm{~m}^{3} \\
8.7 \text { MTHM }\end{array}$ & $\begin{array}{l}\text { Shippingport } \\
\text { PWR }\end{array}$ \\
\hline 4 & Disrupted, low enriched, $\mathrm{UO}_{2}$ & $\begin{array}{l}34 \text { types; } 145 \mathrm{~m}^{3} \\
87.5 \text { MTHM }\end{array}$ & TMI-2 \\
\hline 5 & Disrupted, highly enriched $\mathrm{UO}_{2}$ & $\begin{array}{l}44 \text { types; } 24 \mathrm{~m}^{3} \\
6.2 \text { MTHM }\end{array}$ & TORY \\
\hline 6 & $\begin{array}{l}\text { Intact medium enriched U-zirconium } \\
\text { hydride clad with } \mathrm{Al}, \mathrm{Zr} \text {, } \\
\text { or stainless steel }\end{array}$ & $\begin{array}{l}97 \text { types; } 6.6 \mathrm{~m}^{3} \\
1.8 \mathrm{MTHM}\end{array}$ & $\begin{array}{l}\text { Standard } \\
\text { TRIGA }\end{array}$ \\
\hline 7 & $\begin{array}{l}\text { Some disrupted, highly enriched U- } \\
\text { zirconium hydride clad with } \mathrm{Zr} \\
\text { or stainless steel }\end{array}$ & $\begin{array}{l}24 \text { types; } 1.3 \mathrm{~m}^{3} \\
0.2 \text { МТНМ }\end{array}$ & TRIGA Flip \\
\hline 8 & $\begin{array}{l}\text { Low enriched, } U \text { metal or U alloy } \\
\text { or } \mathrm{Zr} \text { or Mo with various claddings }\end{array}$ & $\begin{array}{l}14 \text { types; } 0.8 \mathrm{~m}^{3} \\
2.0 \text { МТНM }\end{array}$ & HWCTR \\
\hline 9 & $\begin{array}{l}\text { Highly enriched, U metal or U alloy } \\
\text { or Zr or Mo with various claddings }\end{array}$ & $\begin{array}{l}6 \text { types; } 2 \mathrm{~m}^{3} \\
\text { 3.9 МTHM }\end{array}$ & Fermi \\
\hline 10 & $\begin{array}{l}\text { Highly enriched UC in } \mathrm{SiC} \text { coated } \\
\text { particles in a graphite matrix }\end{array}$ & $\begin{array}{l}1 \text { type; } 196 \mathrm{~m}^{3} \\
23 \text { MTHM }\end{array}$ & Fort St. Vrain \\
\hline 11 & $\begin{array}{l}\text { Highly enriched UCin non-SiC coated } \\
\text { particles in a graphite matrix }\end{array}$ & $\begin{array}{l}7 \text { types; } 35 \mathrm{~m}^{3} \\
3 \text { MTHM }\end{array}$ & $\begin{array}{l}\text { Peachbottom } \\
\text { graphite }\end{array}$ \\
\hline 12 & $\begin{array}{l}\text { Highly enriched UC in a non-graphite } \\
\text { matrix }\end{array}$ & $\begin{array}{l}2 \text { types; } 5 \mathrm{~m}^{3} \\
0.06 \mathrm{MTHM}\end{array}$ & SRE \\
\hline 13 & $\begin{array}{l}\text { Highly enriched U-233 with thorium } \\
\text { in } \mathrm{Zr} \text { cladding }\end{array}$ & $\begin{array}{l}1 \text { type; } 52 \mathrm{~m}^{3} \\
39 \text { МТНM }\end{array}$ & $\begin{array}{l}\text { Shippingport } \\
\text { LWBR }\end{array}$ \\
\hline 14 & Metallic sodium bonded & $\begin{array}{l}33 \text { types; } 15 \mathrm{~m}^{3} \\
60 \text { МТHM }\end{array}$ & $\begin{array}{c}\text { Fermi blanket } \\
\text { EBR-II }\end{array}$ \\
\hline 15 & Aluminum clad U compounds & $\begin{array}{l}14 \text { types; } 43 \mathrm{~m}^{3} \\
3.4 \text { MTHM }\end{array}$ & ATR \\
\hline 16 & Others not included above & $\begin{array}{l}5 \text { types; } 4.3 \mathrm{~m}^{3} \\
0.2 \text { МTHM }\end{array}$ & \\
\hline
\end{tabular}

The CPP-666 pool is the most up-to-date storage pool in the DOE complex (Figure 1). Built to store SNF waiting for reprocessing, it is lined with stainless steel and has modern leak detection and water purification systems. Other pools - such as the unlined TAN concrete pool (TAN-608) built in 1955 for the Aircraft Nuclear Propulsion program and used to store TMI-2 fuel — have been emptied and theSNF put in dry storage casks. The Advanced Test Reactor pool supports reactor operations and stores SNF until transfer to the pool at INTEC. 

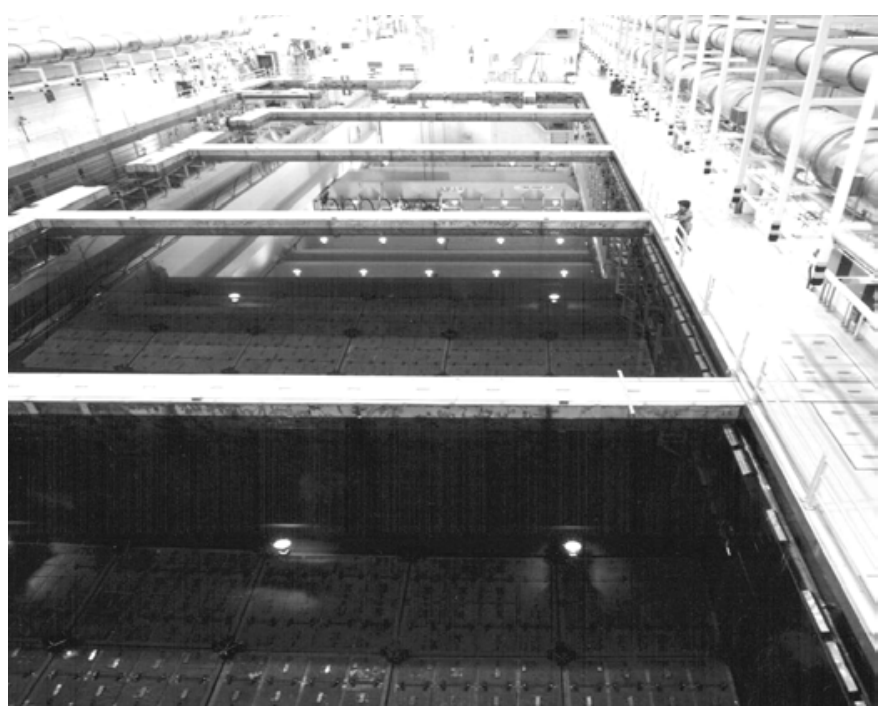

Figure 1. The modern steel-lined CP-666 Storage Pool at the Idaho Nuclear Technology and Engineering Center (INTEC)

\subsubsection{Dry Storage Facilities}

Dry storage facilities are now consolidated at INTEC, MFC and Fort St. Vrain, Colorado. The dry storage casks at TAN SNF storage pad have been relocated to INTEC on a new pad. Commercial light water reactor fuels, bare and consolidated assemblies, have been in various commercial storage casks for up to 15 years under a joint DOE and Nuclear Regulatory Commission (NRC) testing program; Figure 2 shows the casks at the INL.

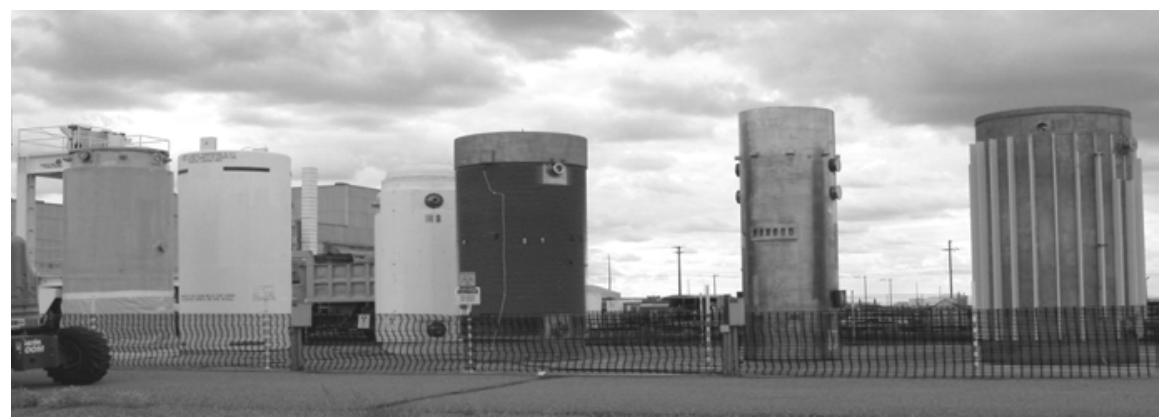

Figure 2. Commercial Dry Storage casks used in SNF tests at the INL Left to Right: REA 2023; VSC-17; TN 24P; V21; 125B; MC-10 
INTEC has four different types of dry storage, not counting the dry storage cask systems. The Irradiated Fuel Storage Facility (IFSF) is an air-cooled vault originally built to store the Fort St. Vrain SNF. It presently stores many different types of SNF. The first generation of storage caisson, CPP-749, has steel-lined below-grade individual vaults, built to store Peachbottom graphite SNF (a general view of the CPP-749 facility is shown in Figure 3). The second generation caissons were a significant improvement in design and were built to store the Shippingport light water breeder reactor SNF.

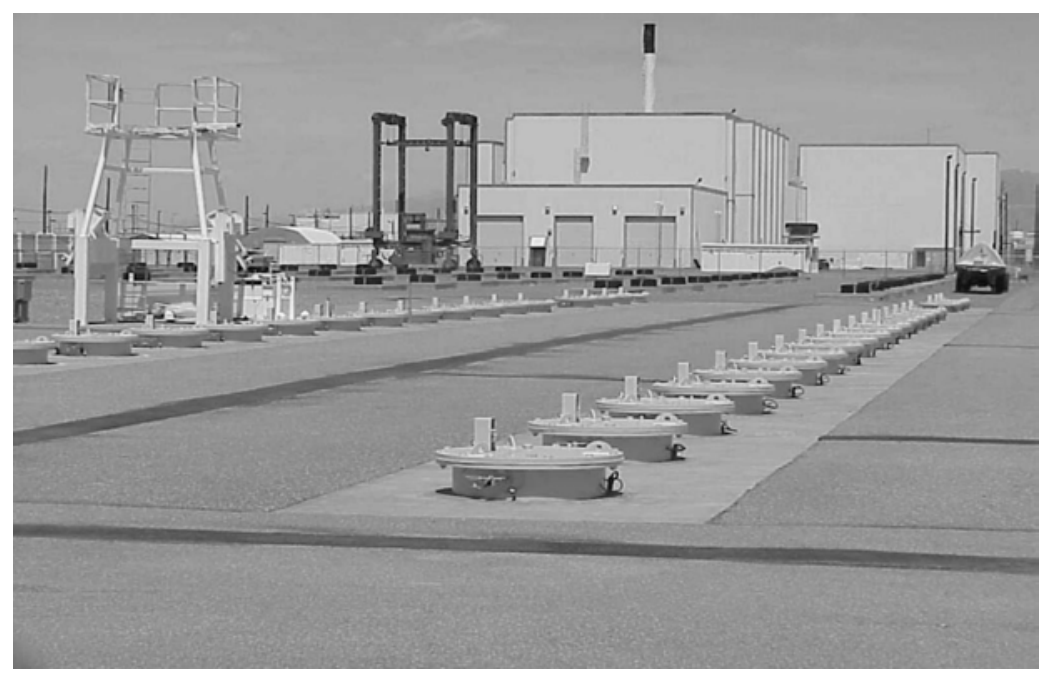

Figure 3. The Below-grade Storage Facility CP-749 at the INL Used to Dry Store Peachbottom Reactor SNF

MFC operates a below-grade silo storage facility (Radioactive Scrap and Waste Facility) which was built in 1965. This facility stores spent fuel and remote handled mixed and radioactive waste, primarily from the EBR-II.

The newest dry storage facility is a modified NUHOMS ${ }^{\circledR}$ design built to hold TMI-2 reactor SNF removed from the damaged core after the accident. This was the second DOE facility licensed by the NRC, and the first one for which DOE actually prepared the license application.

\subsection{RECEIPT AND TRANSFER}

The INL has an active SNF generation and receipt program. The ATR is one of the few operating reactors in the DOE complex, and it is scheduled to operate through 2025. The ATR produces over 30 spent fuel assemblies each year. 
The SNF is cooled in the reactor pool for a short time and then transferred to INTEC for interim management.

The DOE programmatic Environmental Impact Statement (EIS) ${ }^{1}$ and the Foreign Research Reactor EIS ${ }^{2}$ both identify the INL as the receiving location for non-aluminum based SNF presently located at the DOE sites as well as SNF generated in foreign, domestic and university reactors. This includes all SNF containing metallic sodium. The INL will, according to the EIS record of decision, ship all existing INL aluminum-based SNF to the Savannah River Site. MFC will receive sodium-bonded fuel removed from the Fast Flux Test Facility at the Hanford site for treatment. The INL will receive non-aluminum clad SNF from 16 universities, 8 domestic sites, 18 foreign sites and 5 DOE sites.

\section{INL Short -Term Objectives}

\subsection{SAFE INTERIM STORAGE}

Some of the INL SNF facilities have been in operation for over 40 years, although they had an operating lifetime when constructed of 20 years. These facilities do not meet present standards and needed to be shut down and decommissioned. Some of these older facilities contained SNF that has been in storage for over 40 years. The condition of these SNF types deteriorated and presented problems in safe management. Both of these situations were identified as vulnerabilities to the INL and corrective actions taken to eliminate the vulnerabilities. The DOE reached an agreement with the State of Idaho ${ }^{3}$ in 1995 to move the SNF to safe dry storage by 2023 and have it removed from the state by 2035 .

\subsubsection{Consolidate SNF and Shut down Older Facilities}

The INL had several older, wet SNF storage facilities that did not meet present standards ${ }^{4}$. As the SNF was removed from these facilities, these facilities have been shut down and decommissioned. The first facility targeted for this activity was the CPP-603 pool.

The CPP-603 pool consisted of three bare concrete pools that contained a large variety of SNF. The north and middle pools stored SNF that hung from a monorail on hangers that kept the fuel in the proper configuration. There had been considerable corrosion of the carbon steel hangers and the SNF containers. The south pool kept the SNF units in racks that sat on the basin floor. The North and Middle pools were emptied of SNF by 1996. This was accomplished by 
transferring the SNF that was in relatively good condition to CPP-666 and consolidating the SNF that would require additional treatment into the south pool. Remaining fuel in the CPP-603 pool was repackaged into new storage cans or buckets and transferred to CPP-666 or to IFSF. A total of 1340 units of SNF were transferred between 1994 and April 2000. The project was complete 8 months ahead of schedule. Decontamination and decommissioning of the facilities is now underway.

The SNF Storage Pool located at the TAN was also a bare concrete pool that stored SNF in metal racks. The primary SNF type that was stored in the TAN pool was the TMI-2 SNF debris contained in stainless steel containers. There was also some commercial and Loss of Fluid Test SNF in the pool. The TAN facilities, located 20 miles from INTEC, were emptied of SNF in 2002 and the material moved to INTEC.

The MTR canal was a pool that was constructed to support the operation of the MTR reactor and had been maintained to store SNF that was left over from the research and testing programs at the INL. It was a bare concrete pool that contained SNF in storage racks. This SNF was moved to INTEC in 2001.

The PBF pool was a small stainless steel lined pool that was built to support the operation of the PBF reactor. The reactor has been shut down and defueled. The only fuel stored in the pool was the PBF fuel. The INL moved this SNF to INTEC in 2002.

The INL SNF management plan called for moving all the SNF from these older, remote facilities into modern wet or dry storage and eventually all into dry storage. Significant projected cost savings have been realized from the shutdown of these older facilities.

The IFSF plays an important part in the INL consolidation plans. The transfer of all of the INL SNF from wet storage to dry storage is an important step in reducing storage costs as well as meeting the State of Idaho agreement. The IFSF was constructed to store all of the SNF from the Fort St. Vrain reactor in Colorado. Because two thirds of the fuel will remain in Colorado until it is time to prepare it for repository disposal ${ }^{5}$ there is excess room for the storage of other SNF types. SNF was moved out of the older facilities into IFSF and the older, wet storage facilities were shut down without having to wait for new facilities to be built. Much of the SNF that was moved out of the CPP-603 pools was moved into IFSF. The foreign research reactor fuel that is now being received is being put into IFSF, as well as all the SNF removed from the MTR and PBF facilities.

The radioactive scrap and waste facility (RSWF) is used for the bulk of interim fuel storage at MFC. Spent fuel is stored dry, below grade, in passively cooled cathodically protected carbon steel liners or silos. All of the sodiumbonded fuel destined for electrometallurgical treatment will pass through RSWF and the high level waste forms will be stored there awaiting geological disposal. 
The INL constructed an NRC-licensed facility ${ }^{6}$ for the dry storage of the TMI-2 SNF. DOE decided to make this facility the first NRC licensed facility at a DOE site. This design is a modification of an existing NUHOMS ${ }^{\circledR}$ design that was adapted for the TMI-2 SNF.

DOE authorized the construction of a privatized SNF storage facility. The project is called the spent nuclear fuel dry storage project (SNFDSP) and the contract was awarded to Foster Wheeler Environmental Corporation ${ }^{7}$. This facility would initially accept three types of INL SNF but it can be expanded to accept the entire INL SNF inventory. The facility would have the capability to dry and characterize the SNF to meet the repository acceptance criteria. This facility is currently on hold as DOE decides its long-term SNF management approach for the INL.

\subsubsection{Maintaining Capabilities}

MFC has two large inert hot cells which will be maintained in their current operational status. Electrorefining of fuel takes place in the Fuel Conditioning Facility while final waste form production is carried out in the Hot Fuels Examination Facility (HFEF). In addition, HFEF is actively providing spent fuel characterization services to DOE and non-DOE customers alike.

The TAN hot shop is the largest operational hot shop in the United States. It was constructed as part of the Aircraft Nuclear Propulsion program in the 1960s. It was used to service the dry storage casks located on the SNF dry storage pad at TAN. It was also used to dry the debris from the TMI-2 reactor which has been stored underwater at TAN for over 20 years. It is currently being used to support decontamination and decommissioning activities at TAN. This facility is scheduled for shutdown in the Fall of 2006 and will eventually be dismantled.

\subsubsection{Technology Development}

The technology needed to characterize the INL SNF and prepare it to meet repository acceptance criteria did not exist when reprocessing was terminated. The INL began a technology development program to ensure that the technology would be available when it was needed. The program focused on three major areas: drying, conditioning, and non-destructive characterization.

The first technology developed and implemented at the INL was an ultrasonic system to non-destructively look inside sealed stainless steel cans to determine if there was water inside and also to determine the condition of the fuel inside the cans. Many research projects investigated the effects of water on the SNF for long periods of time, and methods to ensure water removal from $\mathrm{SNF}$. The technologies needed for long term dry storage and dispositioning 
include: 1) removing the free and bound water, 2) determining the effects of hydrogen from the radiolysis of water on the materials, 3) material interactions between the SNF and the containers, and 4) material corrosion modeling for all of the SNF and container materials. The technologies needed for conditioning the fuel for repository dispositioning include: 1) removal and stabilization of metallic sodium 2) removal of metallurgical mount epoxy, and 3) methods to ensure that the condition of the fuel after 40 years of dry storage will still meet the transportation and repository acceptance criteria. The technology needed for characterization included non-destructive assay to determine the radionuclide inventory of the container, including the fissile material inventory, and non-destructive examination of the SNF condition.

\subsection{PREPARE FUEL TO MEET STORAGE CRITERIA}

Most of the INL SNF inventory has been stored underwater for many years. Some of the fuel stored as been bare assemblies and some of it has been in cans. For the fuel that has remained intact, the drying is fairly simple. For the fuel that is not intact or that is stored in cans that are not intact, the drying is more involved. One example of the dry process is that designed for fuel being moved into the IFSF from CPP-603 basins. The fuel needed to be hot vacuum dried. The SNF had insufficient decay heat for drying so it had to be actively heated as well as vacuum dried. However, the SNF included aluminum clad SNF what could not be dried at high temperatures. In addition, a drying system had to be designed to fit with in the existing IFSF SNF receiving area.

A second example of a unique drying station is the one designed for the TMI-2 SNF. The debris has been stored in stainless steel cans full of water for over 20 years. The stainless steel canisters also contained low density concrete as well has the SNF debris that had become saturated with water. It was necessary to design a heated vacuum dry system that would heat the debris to over $800 \mathrm{C}$ to drive all of the free as well as the bound water.

\section{INL Long -Term Objectives}

\subsection{REPOSITORY AND TRANSPORTATION REQUIREMENTS}

The SNF and its container will need to meet strict transportation and repository acceptance criteria in order to be transported and dispositioned in a repository. The existing transportation criteria are contained in 10 CFR 71. The INL assumes that these requirements will not change significantly over the next 30 years and plans to package the SNF now so that it will meet these requirements and will not have to be re-packaged prior to shipment to the repository. This 
involves treating the fuel and ensuring the structural and criticality control features employed during packaging will meet the 10 CFR 71 criteria.

The repository acceptance criteria are still evolving as the design of the repository is being developed. There are many of the criteria that are firm enough that design solutions to address them can be developed and implemented now.

\subsubsection{Treatment to meet repository requirements}

Nuclear criticality in the repository was an issue that surfaced early in the repository planning. The initial repository design called for large diameter waste packages. For HEU fuel this design represented a difficult task to show that no criticality would occur over the life time of the repository. During discussion with DOE-Office of Civilian Radioactive Waste Management (RW) the idea of putting only small quantities of HEU in a waste package was determined to simplify the criticality analysis. However, the idea of having to handle a very large number of small diameter waste packages was not appealing to the repository operators.

A concept was identified where the SNF and the HLW glass logs could be packaged together in the same waste package. This allowed the repository to use large diameter waste packages, yet limited the quantity of fissile material in a waste package. This concept was named co-disposal. ${ }^{8,9}$ A design of a waste package that contained a ring of five HLW glass logs around the outside and one SNF canister in the middle was prepared. The utilization of this "extra" space in the waste package would allow the disposition of small quantities of HEU yet not increase the number of waste packages or increase handling costs. The original design has been expanded, the concept has been adopted by RW.

The co-disposal concept also simplified the handling of the INL SNF in the surface facility. Because of the diversity of SNF sizes DOE-RW felt that it would be impossible to design an effective means to handle all of the SNF assemblies one at a time. The original RW surface facility design for SNF handling included moving one assembly at a time from the transportation cask to the waste package. This is still the plan for the commercial SNF, where there is some consistence in the design of the handling fixtures. The standard canister design simplified the handling process for the DOE SNF. Four standard canisters were design. The dimensions of 18 inch and 24 inch diameter were chosen with lengths of 10 feet and 15 feet.

Forty years of research, development and operation of liquid metal cooled fast breeder reactors have generated $\sim 60$ metric tons of heavy metal of sodiumbonded spent nuclear fuel. The bulk of the fuel is from the EBR-II reactor $(\sim 25$ MTHM) and the Fermi reactor (34 MTHM) and is stored at facilities on the INL. This fuel is distinguished from commercial uranium oxide fuel by use of 
uranium or plutonium metallic alloy fuel bonded to the cladding by metallic sodium. The presence of sodium potentially complicates disposal certification and licensing for geological disposal because the draft waste acceptance criteria does not allow spent fuel which contains explosive, pyrophoric, or chemically reactive material ${ }^{10}$. The Record of Decision for the Treatment and Management of Sodium-Bonded Spent Nuclear Fuel chose the electrometallurgical treatment at the MFC as the means to stabilize the chemically reactive sodium found in the EBR-II fuel type. An electrorefiner, using a molten salt electrolyte, is used to separate the sodium and fission products from the fuel meat, resulting in high level radioactive ceramic and metallic waste forms which will be qualified for geological disposal. Treatment of the Fermi fuel has been postponed pending further study of the electrometallurgical and alternative treatment technologies.

A number of INL SNF types consist of small quantities of unique fuel, sometimes referred to as "dogs and cats". A few of these SNF types consisted only a few quart size cans of severely disrupted SNF. In one of the INL SNF task team meetings an observation was made that " if we could just make this fuel as durable as other fuels it would be acceptable". The idea of a high integrity canister (HIC) was born'. A HIC would be constructed out of extremely corrosion resistant materials, such as zirconium with diameters small enough that the container would be critically safe by geometry. The HIC as designed will not corrode over the life of the repository, will not break open even under beyond design basis accidents, and will not go critical. Nuclear criticality analysis will still be necessary because several HICs may be placed into a standard canister.

The presence of organic material in the repository is as yet an unanalyzed potential problem ${ }^{10}$. Several potential scenarios have been hypothesis. Some of the INL SNF contains epoxy in the form of sample mounts for metallurgical examination. These may be considered an organic material. The INL is presently evaluating technologies that might be used to remove epoxy as part of a treatment program to meet repository requirements.

The chemical reactivity of uranium spent fuel is another issue being addressed by researchers at the INL in order to meet repository safety criteria. Uranium hydride can form as a byproduct of aqueous corrosion and its pyrophoric nature is well known. Experiments sponsored by the National SNF Program (NSNFP) at MFC have resulted in a clearer understanding of the oxidation kinetics of uranium hydride under repository conditions ${ }^{11}$.

\subsection{REPOSITORY DISPOSITIONING}

Soon after the decision was made by DOE to terminate reprocessing of SNF for the recovery of enriched uranium and plutonium, the INL began exploring other options for treatment and final disposition of SNF. Initial contacts were made 
with DOE-RW in 1996 and a task team was set up with INL and DOE-RW to evaluate possible options for dispositioning SNF. This task team prepared a report that outlined the direct disposal options for the INL SNF. The INL has also been working very closely with the National SNF Program located at the INL to ensure that all Yucca Mountain planning, recommendations, and licensing activities include the INL SNF. The INL has also opened contacts with the NRC through DOE-RW and the NSNFP ${ }^{8,9}$.

Because of the diversity of the INL inventory it was concluded that each SNF type could not be individually addressed in the repository analysis. An evaluation was performed and it was determined that the SNF types could be grouped by characteristics important to the particular analysis. The group could then be represented by one fuel. This approach greatly simplified the analysis ${ }^{9}$.

The INL SNF was included in the Yucca Mountain Environmental Impact Statement as part of the SNF inventory, and the electrometalurgical products as high level waste (HLW) products. The data included chemical, physical and radiological properties of the material. The INL inventory was included in the analysis of all of the potential impacts. There were no adverse impacts attributed to the INL SNF.

INL SNF is also included in the Yucca Mountain Site Recommendation report that is presently being prepared by DOE-RW and will be included in the repository license application that will be submitted to the NRC. The same grouping approach is being used in these two documents that were used in the EIS, with additional in enhancements in the characterization data.

\subsection{KEY MILESTONES}

The following key milestones relate to the Consent Order and Settlement Agreement. These milestones, if not met, could result in halting all shipments of SNF into the State of Idaho per the terms of the Settlement Agreement.

- Commencement of TMI-2 fuel debris movement from TAN wet basins Completed 03/31/1999,

- Removal of all SNF from CPP-603 wet storage by 12/31/2000 Completed 04/28/2000,

- Removal of TMI-2 fuel debris from TAN wet basins by 06/01/2001 Completed 06/2001,

- Begin loading spent fuel into dry storage (excluding TMI-2 fuel debris covered separately) by 07/01/2003 - Completed 06/2003,

- Removal of all SNF from wet storage by $12 / 31 / 2023$,

- Completion of shipment of SNF from the State of Idaho by 01/01/2035. 


\section{Conclusions}

A legacy of the INL was a large, diverse inventory of SNF in a large number of aging facilities. With termination of reprocessing there was no path forward for disposition of SNF. Managing this legacy has included: characterization of the SNF and facilities, resolving SNF storage vulnerabilities, consolidating SNF and closing facilities, managing domestic and foreign assigned fuel receipts, developing technologies needed, and ensuring that the SNF inventory or its treatment byproducts are acceptable in a federal repository.

\section{References}

1. Department of Energy's Record of Decision for Programmatic Spent Nuclear Fuel Management and Idaho National Engineering Laboratory Environmental Restoration and Waste Management Programs, (60 FR 28680) May 30, 1995 and Amendment, March 1996

2. Department of Energy's Record of Decision for Nuclear Weapons Nonproliferation Policy Concerning Foreign Research Reactor Spent Nuclear Fuel, (61 FR 25092), May 13, 1996.

3. Settlement Agreement, State of Idaho and the Department of Energy, October 16, 1995 re: Public Service of Colorado v. Batt, No. CV 91-0035S-EJL (D. Id.) and United States v. Batt, No. CV-91-0054-S-EJL (D. Id.)

4. Defense Nuclear Facilities Safety Board Recommendation 94-1 to the Secretary of Energy, May 1994 and DOE Implementation Plan, February 28, 1995

5. Settlement Agreement, Contract No. DE-AC07-96ID13425, February 9, 1996, between the United States Department of Energy and Public Service Company of Colorado, Modifying Contract at (04-3)-633, as amended, and Agreement No. DE-SC07-79ID01370, as amended.

6. INEEL ISS Facility Project DE-AC07-99ID13727

7. Spent Nuclear Fuel Dry Storage Project DE-AC07-00ID13729

8. Technical Strategy for the Treatment, Packaging, and Disposal of Aluminum Plate Fuels, June 1996

9. Technical Strategy for the Management of INEEL Spent Nuclear Fuel, Volume I, March 1997

10. Civilian Radioactive Waste Management System, MGDS Waste Acceptance Criteria, B00000000-01717-4600-00095, Rev. 00, Draft A, September 1997

11. "Oxidation Kinetics of Hydride-Bearing Uranium Metal Corrosion Products", T.C. Totemeier, R.G. Pahl, and S.M. Frank, Journal of Nuclear Materials 265 (1999) 308-320. 